\title{
Policies for the prevention of cigarette consumption: the case of Spain
}

\author{
Ángel López Nicolás ${ }^{1}$ and Jaime Pinilla Domínguez ${ }^{2}$ \\ 1 Department of Economics and Business and CRES, Universitat Pompeu Fabra, Barcelona and Departamento de Economía, Universidad Politécnica \\ de Cartagena, Cartagena, Spain \\ 2 Department of Quantitative Methods in Economics, University of Las Palmas de Gran Canaria, Las Palmas, Spain
}

\begin{abstract}
This paper describes the causes that generate the relatively high - among comparable OECD countries - prevalence of tobacco consumption in Spain. It evaluates the current policy interventions geared towards reducing incidence and prevalence. It argues that, despite a recent major breakthrough in legislation on advertising and consumption in public places, one of the major shortcomings of current policies is the lack of an effective fiscal policy. This lack of effectiveness is explained by some idiosyncrasies of the Spanish cigarette market that call for specific measures.
\end{abstract}

Keywords Cigarettes, taxation, health, Spain.

\section{Overview}

Smoking is probably the most important public health problem afflicting the Spanish society. Since the 1980s, healthcare professionals have articulated a prevention movement with increasing presence in the media and influence in policy making. The National Plan for Prevention and Control of Tobacco (NPCPT or Plan hereafter) approved in 2003 attempts to co-ordinate anti-smoking actions in the public sphere by engaging all layers and sectors of government. This paper will argue that the NPCPT and its ensuing legislation represent a turning point in the Spanish situation. However, long-run success in abating the smoking epidemic in Spain will crucially depend on the development of

\section{Correspondence}

Ángel L. Nicolás, Departamento de Economía, Universidad Politécnica de Cartagena. Paseo Alfonso XIII, 50. 30203 Cartagena, Spain. E-mail: angel.lopez@upct.es effective fiscal measures. In order to develop this point, section 2 presents a brief overview of the characteristics of the smoking epidemic in Spain and the prevention policies at the turning of the century. Section 3 describes the main features of the NPCPT and its major outcomes to date, the Spanish government proposal to prohibit smoking in public and private work areas and a total ban on advertising. Section 4 discusses the taxation of cigarettes and in particular the factors that might represent an obstacle to the effective use of fiscal policies and suggests specific actions taken in markets with a similar structure. Section 5 concludes and summarizes the main lessons of interest for prevention policies elsewhere.

\section{The tobacco epidemic in Spain at the end of the XX century}

Smoking prevalence in Spain is relatively high. The figures in Table 1 illustrate the Spanish situation in relation to OECD countries. Firstly we observe that the prevalence of daily smokers is six points above the average. In the second column we find that, except for Belgium and Germany (the latter perhaps reflecting the reunification effect), the prevalence of daily smoking has decreased in all countries. The pattern of reduction is heterogeneous: while Denmark witnessed a reduction of roughly one-third, the Spanish figure remained practically immobile. The aggregate Spanish figure in fact masks a differential behaviour between men and women. While the prevalence in men decreased from $65 \%$ in 1970 to $42.1 \%$ in 2001 , the female figure increased from $17 \%$ to $27.2 \%$ during the same period. These features place the Spanish population between phases III and IV of the smoking epidemic. Other than an equalization of prevalence rates across genders, the fourth phase of the tobacco epidemic is characterized 
Table 1 Prevalence of daily smokers in a selection of industrialized countries

\begin{tabular}{llr}
\hline Daily smokers, prevalence & 2001 & Decrease over 1990s \\
\hline Australia & 19.8 & 6.2 \\
Belgium & 28 & -0.1 \\
Canada & 18 & 9.1 \\
Czeck Republic & $23.5^{*}$ & 2.6 \\
Denmark & 29.5 & 13.8 \\
Finland & 23.8 & 1.9 \\
France & 27 & 2.8 \\
Germany & $24.7^{*}$ & -1.0 \\
Greece & $35^{* *}$ & 4.5 \\
Iceland & 23.6 & 5.5 \\
Ireland & $27^{* * *}$ & 2.3 \\
Italy & 24.1 & 2.7 \\
Japan & 32.7 & 4.5 \\
Korea & $30.4^{* *}$ & 4.3 \\
Luxembourg & $32^{* * *}$ & 1.0 \\
Holland & 34 & 3.0 \\
New Zealand & 25 & 2.0 \\
Norway & 30 & 5.3 \\
Poland & 27.6 & 13.9 \\
Portugal & $20.5^{*}$ & $\mathrm{n} . \mathrm{d}$ \\
Spain & 31.7 & 0.4 \\
Sweden & 18.9 & 6.1 \\
United Kingdom & 27 & 2.0 \\
USA & 18.5 & 4.0 \\
Average & 25.8 & 4.2 \\
\hline & & \\
\hline
\end{tabular}

Figures as percentage over population: *Figure for 1999; **Figure for 2000; ***igure for 1998.

Source: OECD (2003) Health Data.

by a strong social class gradient in the consumption of tobacco, with prevalence concentrated among poorer individuals. In contrast, in the third phase the prevalence in women is smaller than in men and the social gradient is weak (Villalbí, 2002).

Why is smoking prevalence greater in Spain than in countries of its socio-economic context?

Part of the explanation lies in the fact that the epidemic was developed with some delay in Spain, but also because the public sector did not react promptly to the first scientific evidence about the hazards of smoking (Villalbí, 2002). It is widely accepted that the main barrier opposing preventive policies is constituted by the economic interests of the tobacco industry (CDCP, 1999), against which political action is required (Villalbí and López, 2001). Taking this premise into account, it is easy to understand part of the differential position of Spain: a delayed access to democracy and development of the modern public sector. The smoking problem has not been a public concern - because other social problems have been perceived as more urgent - and it therefore did not make it into the political agenda. In this context, it is not surprising that the first prevention initiatives arrived late. The first legal attempts to regulate advertising and smoking in public places were made at the end of the 1980s. Similarly, due to the recent modernization of the primary healthcare network, a substantial proportion of the population has not received GP advice against tobacco use until very recently (Villalbí, 2002).

The tobacco industry has been successful at influencing public opinion in order to maintain the status quo. A recurrent argument against control policies is that of freedom 'under threat'. This message has been warmly welcomed by a society with recent memories of the Franco dictatorship and it is possibly one of the factors leading to the huge increase in female prevalence since the 1970s (Salvador, 2000). As far as the industry's ability to influence policy making, it is necessary to remark that until 1988 the Spanish state held the majority of the shares of Tabacalera (the state tobacco monopoly). The Spanish public sector held until very recently around $2 \%$ of Altadis, the result of the merger between Tabacalera and the French state tobacco monopoly Seita, and currently the main firm by sales volume in the Spanish market (SEPI, 2004). As we will argue, the current fiscal structure is a result of the implicit desire to protect the firm resulting from the privatization of the state monopoly.

Anti-smoking policies at the end of the XX century in Spain could be catalogued, according to the terminology used by the World Health Organization (WHO, 2002a), as being of 'weak impact' because they have neither sufficient legislative power against advertising nor fiscal content. In fact, while tobacco products have been banned from TV advertisements in Spain, the most vulnerable population - adolescents - were, until the end of 2005, subject to an important advertising bombardment via the sponsorship of concerts, sport events, 
Figure 1 Retail price for the most popular brand of cigarettes in purchasing power parity (PPP) terms in the EU15 countries. Source: Excise Duty Tables. European Commission. Note: AT, Austria; BE, Belgium; DE, Germany; DK, Denmark; EL, Greece; ESPAÑA, Spain; FI, Finland; FR, France; UK, United Kingdom; IE, Ireland; IT, Italy; LU, Luxembourg; NL, Holland; PT, Portugal; UE15, average for the European Union (pre 2004 enlargement).
Retail price for most popular brand (PPP adjusted)

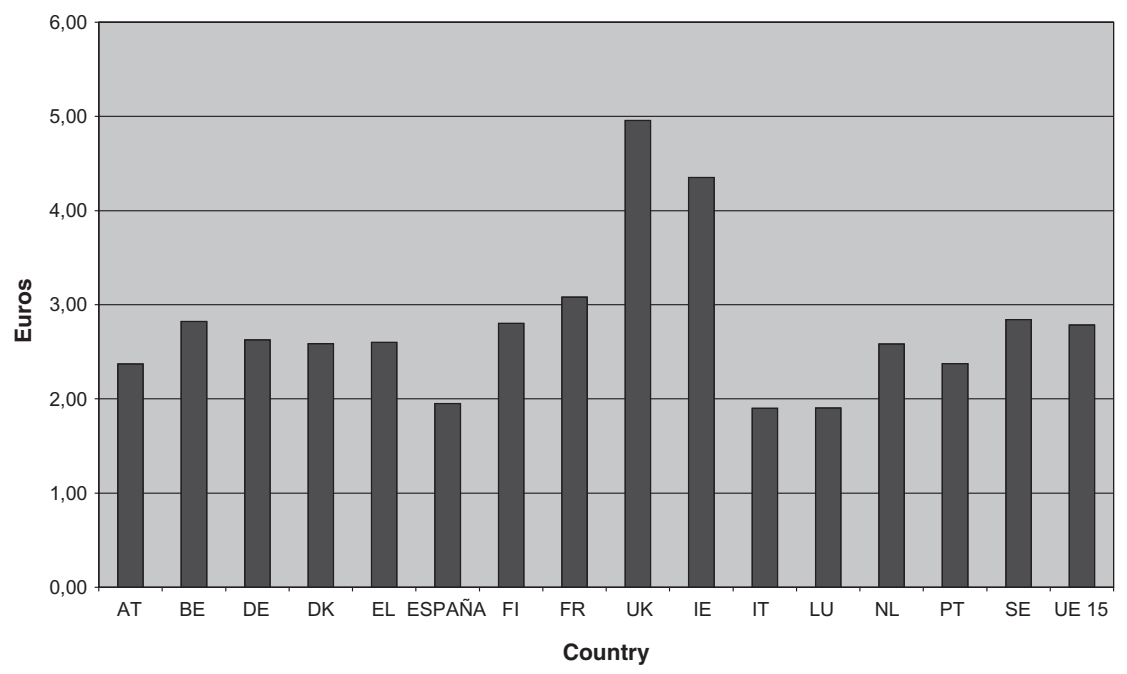

etc. As far as taxes are concerned, the current situation allows one of the lowest levels of retail prices in real terms in the European Union (EU), as Fig. 1 shows.

\section{Recent policy innovations: the national plan for the prevention and control of tobacco and the law of health measures against smoking}

During the 1980s, a group of public health professionals started to call for a co-ordinated prevention policy while, simultaneously, the first epidemiological studies on the effects of smoking on the Spanish population were published. These initiatives led eventually to the creation of the National Committee for the Prevention and Control of Tobacco (NCPCT) in 1996, a nongovernmental organization including a long list of professional medical associations (Villabí et al., 2004). The NCPCT contributed to the introduction of the smoking problem into the political agenda. The approval in 2003 of the NCPCT (MSC, 2002) was the result of the momentum gathered by the prevention movement. The Plan responded to the guidelines of the WHO's Third Action Plan for a Europe Without Smoking (WHO, 2002b), which reckons the necessity to address the problem from an intersector point of view.
The Plan established three main objectives to be achieved by 2007. First, to reduce smoking prevalence to a level below $28 \%$; second, at least $65 \%$ of the population must be protected from environmental tobacco smoke; and third, to co-ordinate all actions and initiatives (MSC, 2002).

At the time of writing this paper, the main legislative transposition of the principles embodied in the Plan is the Law of Health Measures Against Smoking (the Law hereafter). This Law has been enforced on 1 January 2006.

\section{The main features of the Law}

Prior to the Law, smoking was already prohibited in all hospitals, educational establishments and public administration premises, in all urban and long-distance vehicles, on all domestic flights of less than $90 \mathrm{~min}$, and in workplaces where smoking may pose an increased health risk (i.e. for pregnant women or children).

The Law contains a comprehensive ban on advertising (it incorporates EU legislation into the Spanish legal system in this respect) and stringent restrictions on consumption and sales of tobacco. In particular, the Law bans smoking at all workplaces except bars and 
restaurants. For these places, if the business premise has less than $100 \mathrm{~m}^{2}$, managers have to decide whether they opt for a smoke free environment or they allow smoking. Bigger premises are non-smoking by default, but managers can set up a fully separated smoking area.

The Law is based on scientific evidence about the effects of environmental tobacco smoke (USEPA, 1992; Hackshaw et al., 1997; Kreuzer et al., 2000), especially on workers at bars and restaurants. Jamrozik (2005) estimates that second-hand smoke causes one premature death a week among workers in the hospitality industries. Smoke-free workplaces will therefore protect all workers and will encourage smokers to quit (Fichtenberg and Glantz, 2002; Mandel et al., 2005).

Elsewhere in Europe, complete bans on smoking in bars and restaurants (including workplaces) have been introduced in Ireland (since March 2004), Norway (June 2004), Italy (January 2005) and Sweden (June 2005).

\section{Hospitality industry reactions and obstacles to implement the restrictions to consumption in public places}

Legislation to ban smoking in bars, restaurants, casinos and discotheques is a controversial issue. Smokers might accept bans at their workplace, but might resent not being able to smoke at pubs and bars. This generates fears about potential loss of business in the hospitality sector. In turn, workers unions are worried about potential loss of employment. However, recent evidence on the impact of exposure to second-hand tobacco smoke combined with studies showing no loss in sales after a smoking ban in some countries have generated support for smoking bans among trade unions (Sciacca and Ratliff, 1998).

The Law has to face a cultural scene of tolerance towards smoking in public places. Many bar and restaurant owners argue that the new rules will deter clients and they lack the resources to create sealed-off smoking areas. They also protest against a requirement to report on customers who break the Law.

For these reasons, bar and restaurant associations have announced challenges in the courts. Similarly, smokers' groups have campaigned against the Law. For instance, during the summer of 2005, an organization called 'Fumadores por la Tolerancia' ('Smokers for Tol- erance') organized a campaign 'Prohibido Prohibir' ('It is Forbidden to Forbid') to retard the Law.

Many people believe that Spanish smokers would simply ignore the ban due to the traditional Mediterranean view that laws, especially those regarding tobacco consumption, are 'merely informative'.

So how will the Spanish people react to what might be a strong cultural change? Clearly, the chances of success depend on whether accompanying fiscal measures are taken. The following section analyses the economic characteristics of the Spanish market for cigarettes and proposes fiscal changes geared to accompany the public health measures contained in the Law.

\section{Taxes: the pending reform}

Although the 2003 Plan included the use of taxes as a prevention instrument, the Law does not include any provision on fiscal matters. As a result, this is one of the aspects of prevention where Spain has a long way to go in comparison with other countries. The reasons are varied. At a general level, many economists think that the level of public intervention in the tobacco market is already enough. Besides, the Spanish market has special features that fetter the effective application of taxes. This section analyses these factors and proposes measures to overcome the current deficit in this crucial aspect of prevention.

As in other European countries, the Spanish market contains three segments of blond cigarettes (premium, mid-price and low-price). The leading brand in each of the segments is Marlboro (Phillip Morris), Chesterfield (Phillip Morris) and, the most popular brand by volume of sales, Fortuna (Altadis). In addition, there is a lowerprice segment of black cigarettes that makes up around $17 \%$ of sales where the leading brand is Ducados (Altadis). In this sense, the Spanish market is similar to the French market, where the leading brand in the black segment is Gauloises Brunes (Altadis). In both Spain and France, Altadis is more exposed to the low-price segments than the premium or mid-price segments, where Phillip Morris is the leader by sales.

Another similarity between Spain and France is the use of proportional taxes in detriment of specific taxes. The EU directives for cigarette taxes impose a particu- 
Figure 2 Ad valorem tax component in the EU15 countries. Source: Excise Duty Tables. European Commission. Note: AT, Austria; BE, Belgium; DE, Germany; DK, Denmark; EL, Greece; ESPAÑA, Spain; FI, Finland; FR, France; UK, United Kingdom; IE, Ireland; IT, Italy; LU, Luxembourg; NL, Holland; PT, Portugal; UE15, average for the European Union (pre 2004 enlargement).
Ad valorem tax $(\%$ on retail price)

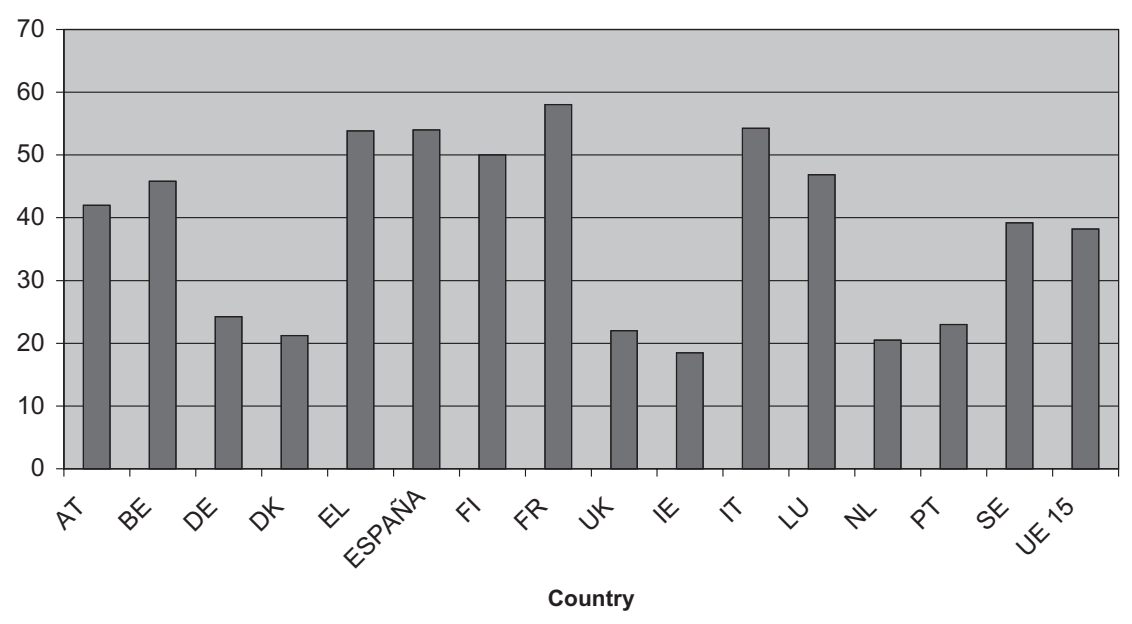

lar structure to be applied by all members. In particular, cigarettes must support the following fiscal elements:

Specific tax (also known as linear component): This is added to the producer's price. This element is crucial at determining a minimum-price threshold.

Ad valorem tax (or proportional component): This is a percentage over the retail price.

In addition, member countries apply

Value-added taxes (VAT): As for other goods and services, this is a percentage over the retail price.

EU law establishes that rates have to be set so as to make the most popular brand fulfil the following conditions:

1 The total special tax fiscal burden (specific tax $+\mathrm{ad}$ valorem tax) must be at least $57 \%$ of the retail price and must yield at least 60 euros per 1000 cigarettes.

2 The specific tax must represent between $5 \%$ and $55 \%$ of the total fiscal burden (specific tax $+\mathrm{ad}$ valorem + VAT).

The proportional tax components tend to reflect producer prices differences between brands in the retail prices, while the specific tax element tends to cushion producer price differences. In Figs 2 and 3, we observe that in both Spain and France, the ad valorem rate is one of the greatest in the EU while their specific rates are among the lowest. This preference for proportional taxation is a response to the desire to protect the firms that are exposed to low-price segments (Delipalla and O'Donnell, 2001). Given the current level of producer prices, and other things being equal, an increase in the specific component would tilt the relative price structure in a way such that brands in the low-price segments would become more costly in relation to those in the high-price segments.

A consequence of proportional taxation is a long range of prices, permitting a substantial degree of downtrading - i.e. to switch to cheaper brands as taxes go up. Since the rates are set so that the most popular brand fulfils the above conditions, it is always possible to launch new brands that fill the price slot left vacant by the most popular brand when its price increases. This allows falling real prices for the basket of products at the bottom of the market. In fact, the reaction of the tobacco industry to the imminent enactment of the Law has been to exploit this fiscal loophole and launch an aggressive campaign of cheap brands. For instance, Altadis has launched a blonde tobacco product under its Ducados brand for 1.35 euros per pack to compete with other low-cost products such as Elixyr from Heinz Van Landewyck and Excite from Van Eicken. In accordance, Philip Morris has lowered the price of its Basic and Next brands to 1.30 euros per pack from 2.10 euros previously.

In these circumstances, a comprehensive prevention policy must address the issue of low prices. Given the 
Specific tax component ( $€$ per 1000 cigarettes)

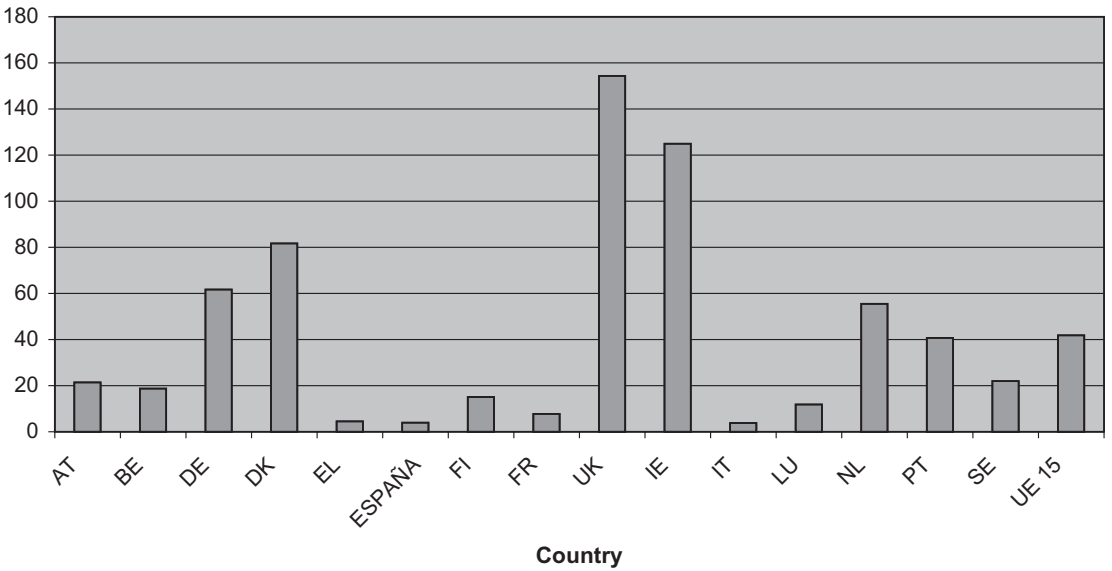

Figure 3 Specific tax component in the EU15 countries. Source: Excise Duty Tables. European Commission. Note: AT, Austria; BE, Belgium; DE, Germany; DK, Denmark; EL, Greece; ESPAÑA, Spain; FI, Finland; FR, France; UK, United Kingdom; IE, Ireland; IT, Italy; LU, Luxembourg; NL, Holland; PT, Portugal; UE15, average for the European Union (pre 2004 enlargement). similarities between the Spanish and French markets, it is worth looking at trends in neighbouring countries in order to consider realistic possibilities for change.

\section{The French model}

EU directive 2002/10/CE opens the possibility of restricting the long tail of low prices below the most popular brand. Member states must be able to avoid price wars and/or the appearance of products that distort the market (as a falling real price for products at the bottom end of the market). A means of achieving this is to allow each member state to levy a minimum special tax on cigarettes, thus creating a floor for cigarette prices.

France applies this type of tax, which explains why retail prices are greater in France than in Spain. Fixing a minimum tax gives a good degree of initiative to a member state. In France, the level of the minimum tax has increased in a sustained way in the last few years. In 1999, France applied a minimum of 78 euros per 1000 units for blond cigarettes and 66.3 euros per 1000 units for black cigarettes. The two rates were unified and in 2003 the minimum was 106 euros per 1000 units. At 9\% per year, this increase is well above Consumer Price Index inflation. The effect of these measures on the structure of prices is compelling. The average price in France (4.6 euros) is much greater than in Spain (2.2 euros). Also, the dispersion of prices around the mean in Spain (standard deviation 0.53 euros) is greater than in France (standard deviation 0.19 euros) and, of great importance for prevention, the minimum price in France is 4.25 euros, whereas in Spain it is possible to buy a pack of 20 cigarettes for 1.2 euros.

Interestingly, the effects of these fiscal measures on smoking in the French population have been significant. A survey (INPES, 2004) suggests a $12 \%$ decrease in prevalence.

\section{Summary and conclusions}

The Spanish society is currently moving towards a stage of 'high impact' policies in the area of tobacco prevention. A major breakthrough has been achieved by means of a Law designed to ban advertising and to restrict consumption in public places. This paper has argued that this breakthrough is the result of political will, demonstrating that non-governmental organizations have an important role in countries where tobacco control policies are at an earlier developmental stage.

This paper has also argued that further advances are needed in the area of taxation. In this sense, the changes cannot be limited to the minimum set by the EU directives, which in the fiscal sense seem to have been designed to provide a soft landing for new entrants. The surprisingly low level of prices in Spain is associated with an industrial structure where the market leader until recently was partially owned by the public sector. 
The French experience provides a useful reference as to how to proceed. The introduction of a minimum yield tax, together with a rise in the specific component would contribute to raising the average level of prices and to avoiding a long tail of low-cost brands. Governments in the enlarged EU also need to consider the provisions of the European directives as a minimum requirement rather than a maximum threshold. In particular, they should consider taking advantage of the possibility of establishing a minimum level of tax revenue per cigarette and update this minimum with inflation. This is relevant not only for new EU countries, but also for countries which are currently considering reforms in the taxation of tobacco products.

\section{Acknowledgements}

Financial support from the Ministerio de Educación y Ciencia under project SEJ2005-09104-C02-02 is gratefully acknowledged.

\section{References}

Centre for Diseases Control and Prevention (CDCP) (1999) Best Practices for Comprehensive Tobacco Control Programs. US Department of Health and Human Services, Atlanta, GA.

Delipalla, S. \& O'Donnell, O. (2001) Estimating tax incidence, market power and market conduct: the European cigarette market. International Journal of Industrial Organisation, 19, 885-908.

Fichtenberg, C. \& Glantz, S.A. (2002) Smoke free workplaces substantially reduce smoking: a systematic review. British Medical Journal, 325, 188-191.

Hackshaw, A., Law, M. \& Wald, N. (1997) The accumulated evidence on lung cancer and environmental tobacco smoke. British Medical Journal, 315, 980-988.

Institut national de prevention et d'education pour la santé (INPES) (2004) Les Chiffres du Tabac: 2003. [WWW document]. URL http://www.cnct.org/site/ article.php3?id_article $=78$.

Jamrozik, K. (2005) Estimate of deaths among adults in the United Kingdom attributable to passive smoking. British Medical Journal, 330, 812.

Kreuzer, M., Krauss, M., Kreienbrock, L., Jockel, K.H. \& Wichmann, H.E. (2000) Environmental tobacco smoke and lung cancer: a case-control study in Germany. American Journal of Epidemiology, 151, 241250.

Mandel, L.L., Alamar, B.C. \& Glantz, S.A. (2005) Smoke-free law did not affect revenue from gaming in Delaware. Tobacco Contrology, 14, 10-12.

Ministerio de Sanidad y Consumo (MSC) (2002) Plan Nacional de Prevención y Control del Tabaquismo 2003-2007. Ministerio de Sanidad y Consumo, Madrid.

Organisation for Economic Co-operation and Development (OECD) (2003) Health Data. Organisation for Economic Co-operation and Development, Paris.

Salvador, T. (2000) Medios de Comunicación y opinión pública. In El Tabaquismo en España: Situación Actual y Perspectivas para el Movimiento de Prevención. Informe SESPAS 2000 (ed. by C. Álvarez \& S. Peiró), pp. 53-69. Escuela Andaluza de Salud Pública, Andalucía.

Sciacca, J. \& Ratliff, M. (1998) Prohibiting smoking in restaurants: effects on restaurant sales. American Journal of Health Promotion, 12, 176-184.

Sociedad Estatal de Participaciones Industriales (SEPI) (2004) Ficha de Privatización: Altadis (Tabacalera). [WWW document]. URL http://www.sepi.es.

US Environmental Protection Agency (USEPA) (1992) Respiratory Health Effects of Passive Smoking: Lung Cancer and Other Disorders. Office of Health and Environmental Assessment, Publication No EPA/600/6-9/ 006F, Washington, DC.

Villalbí, J.R. (2002) El tabaco como problema de salud pública. In Invertir para la Salud: Prioridades en Salud Pública. Informe SESPAS 2002 (ed. by J.N. Cabasés, J.R. Villalbí \& C. Aibar), pp. 113-129. Escuela Valenciana de Estudios para la Salud, Valencia.

Villalbí, J.R. \& López, V. (2001) La prevención del tabaquismo como problema político. Gaceta Sanitaria, 15, 265-272.

Villabí, J.R., Salvador, T. \& Granero, L. (2004) El movimiento de prevención y su organización: papel del Comité Nacional de Prevención del Tabaquismo. In Tratado de Tabaquismo (ed. by C. Jiménez), pp. 571-580. Aula Médica, Madrid.

World Health Organization (2002a) European Strategy for Tobacco Control. Regional Office for Europe, Copenhagen.

World Health Organization (2002b) The European Report on Tobacco Control Policy. Regional Office for Europe, Copenhagen. 